\title{
CTBP2 Gene
}

National Cancer Institute

\section{Source}

National Cancer Institute. CTBP2 Gene. NCI Thesaurus. Code C24318.

This gene is involved in the inhibition of both transcription and cell proliferation. 